\title{
Public Works Heritage 3D Model Digitisation, Optimisation and Dissemination with Free and Open-Source Software and Platforms and Low-Cost Tools
}

\author{
Sara Peinado-Santana, Patricia Hernández-Lamas * ${ }^{\mathbb{C}}$, Jorge Bernabéu-Larena * ${ }^{\mathbb{C}}$, Beatriz Cabau-Anchuelo \\ and José Antonio Martín-Caro \\ Fundación Miguel Aguiló (FMA), School of Civil Engineering, Technical University of Madrid (UPM), \\ 28040 Madrid, Spain; sara.peinado.santana@gmail.com (S.P.-S.); beatriz.cabau@upm.es (B.C.-A.); \\ jmc@inesingenieros.com (J.A.M.-C.) \\ * Correspondence: patricia.hlamas@upm.es (P.H.-L.); jorge.bernabeu@upm.es (J.B.-L.)
}

Citation: Peinado-Santana, S.; Hernández-Lamas, P.; Bernabéu-Larena, J.; Cabau-Anchuelo, B.; Martín-Caro, J.A. Public Works Heritage 3D Model Digitisation, Optimisation and Dissemination with Free and Open-Source Software and Platforms and Low-Cost Tools. Sustainability 2021, 13, 13020. https://doi.org/10.3390/su132313020

Academic Editors: Enrico Cori and Lucia Marchegiani

Received: 14 September 2021

Accepted: 21 November 2021

Published: 24 November 2021

Publisher's Note: MDPI stays neutral with regard to jurisdictional claims in published maps and institutional affiliations.

Copyright: (c) 2021 by the authors. Licensee MDPI, Basel, Switzerland. This article is an open access article distributed under the terms and conditions of the Creative Commons Attribution (CC BY) license (https:/ / creativecommons.org/licenses/by/ $4.0 /)$.
Abstract: This paper describes an innovative, accessible, and sustainable method for enhancing cultural heritage. Documenting and disseminating the public works heritage have now come of age, digitally speaking, with the adoption of new technologies both to further research on and heighten the esteem attributed to the public works heritage. Nonetheless, academic discourse rarely describes procedures for the 3D digitisation of heritage works comprehensible to non-expert readers with limited resources. Taking that premise as a starting point, with special attention to the determinants of the public works heritage, this article aims to define the general, open-source methodology covering 3D model data capture, information processing and optimisation. The article also discusses model dissemination strategies using free platforms and low-cost tools. The general discussion is illustrated with the case study of Ariza Bridge in Spain. This Renaissance-style structure dates from the second half of the sixteenth century. Despite its listing as a cultural heritage asset, the monument was flooded by the Giribaile reservoir waters in 1998 and is now only wholly visible during droughts. The application, developed with open-source software and implemented with free platforms and low-cost tools, features geo-referencing and is designed to be accessible to non-expert users. The methodology proposed is intended as a suitable instrument for the sustainable study, valorisation and dissemination of the built heritage.

Keywords: cultural heritage; civil engineering; digital transformation; photogrammetry; sustainable study; sustainable development; 3D model; holography; augmented reality

\section{Introduction}

Sustainability should be one of the key drivers in any action relating to the cultural heritage. This analysis of the built and in particular the public works heritage, i.e., bridges, roads, canals, dams or ports, with a relevant territorial significance, proposes sustainable methodologies with the use of new technologies based on open-source software, free platforms and low-cost tools.

Unlike architectural heritage, which has been the object of years of research by various schools of thought, public works are poorly delimited and scantly explored and their fundamentals have been insufficiently developed [1]. Until well into the second half of the twentieth century, only engineering works regarded as exceptional further to classical criteria merited attention [2]. Until that time significant (necessarily pre-Industrial Revolution) civil works were deemed to form part of the archaeological heritage. That changed in the 1970s with the onset of the earliest European movements calling for acknowledgement of the historic values of the Industrial Revolution [3] and the appearance of so-called industrial archaeology. Even today, however, in the national plans drafted by Spain's Cultural Heritage Institute, public works are still scattered across several other categories: the industrial heritage, cultural landscape and twentieth century heritage $[4,5]$. 
Studies by a number of mostly academic authors have defined and analysed the specific features of the history, evolution and heritage of public works, while defending their particularities in terms of scale, public ownership, association with use, site and geographic scatter [6-12]. That territorial dimension affords them a conclusive role in the formation of the cultural landscape which, since the 2000 Florence Convention, is regarded as essential to the nature and identity of European diversity [13].

To date, most institutions entrusted with safeguarding a country's cultural heritage have limited their intervention and management to drawing up inventories of the most emblematic public works, covering long time spans and a wide spectrum of typologies. The United Kingdom [14], Ireland [15] and Japan [16] are cases in point. Some outstanding, firmly consolidated initiatives are nonetheless in place, such as the American Society of Civil Engineers' Historic Civil Engineering Landmark Programme [17] or the Institution Engineers Australia's Engineering Heritage Recognition Programme [18], which heighten public awareness of and esteem for civil engineering works with commemorative plaques and online databases.

In Spain, most conceptual and methodological research identifying, characterising and appraising the public works heritage has produced little more than inventories and catalogues [19-25], a few exhibitions [26] and seminars [27]. In recent years, however, new and more comprehensive approaches have been developed that emphasise the territorial significance of public works and their cultural heritage management. Such endeavours are fostered and supported by specific institutions that further public works heritage research and dissemination: Centre for Historic Studies on Public Works and Urban Planning, CEHOPU (1983), Fundación Juanelo Turriano (1987) and Demetrio Ribes Chair (2003). A fourth organisation, Fundación Miguel Aguiló (2009), gears its efforts to the use of new technologies to heighten general awareness of the engineering heritage [28,29]. It has sponsored initiatives such as G•O•ING Grandes Obras de INGeniería [30], VAPROP_Rutas, GEOPACK [31] and PHDuero, which in 2015 was awarded the Hispania Nostra Prize for good cultural heritage conservation practice [32].

It is therefore necessary to continue researching and implementing new approaches and latest generation tools to heighten awareness of the heritage of public works, with new forms of dissemination and management of heritage information that are adapted to today's society. In this sense, the above references to cultural heritage management should be framed in the general context of the global challenge of digital transformation.

Digital transformation is a necessity for cultural organisations. The strength and vertiginous speed with which digitalisation has entered and has taken over our lives has meant that many organisations have not been able to adapt to it yet [33]. These transformation processes can draw on key lessons that have helped lead organisations through digital transformations that succeeded [34] and from the literature that describes the aspects of digital transformation in the public sector and how it is related to knowledge management [33]. Knowledge management is a powerful tool to guide digital transformation of cultural organisations [35].

\subsection{Digitising Heritage}

Until recently, graphic documents on cultural assets were the product of manual architectural surveys using instruments such as yardsticks, plumb bobs and laser distance meters. That methodology delivered graphics consisting in plan, elevation and crosssectional drawings and construction details whose quality and accuracy depended heavily on the author's experience and skill. More recently, however, with the advent of socalled cultural computing [36] and constant advances in information technology, the generation and dissemination of 3D data have become widespread with the nearly universal use of digital photogrammetry and 3D laser scanners in heritage asset surveying and data collection.

Digital photogrammetry and laser scanners are often complementary techniques that define a series of points in space whose density depends on the scanner points or, in digital 
photogrammetry, camera resolution. The decision to use one or another system is based less on their technical specifications than on questions of speed, versatility and accessibility [37] that define the differences between the two. Due to their high cost and the need for specific technical training to correctly process and interpret the data they deliver, laser scanners are less generally accessible than photogrammetry [38].

One constraint that affects both technologies is the dependence of spatial data collection on the distance from the object and its visibility from the point of capture. Gathering data on elements inaccessible from or standing high off the ground calls for the use of unmanned aerial vehicles (UAVs), also known as drones.

Building information modelling (BIM) philosophy is consistently applied to projects for documenting, intervening in and monitoring the built heritage. It is a collaborative working methodology for managing building or civil construction design with a digital scale model generated jointly by all the actors involved [39]. Although the possibility of applying BIM to heritage structures was posed many years before [40], HBIM (historic building information modelling) was not introduced until 2009 [41]. The key to the use of BIM to survey and rebuild the built heritage lies in applying photogrammetric or laser scanned data to generate a core virtual parametric model into which all other data yielded by research and intervention on the built heritage can be entered [42] (p. 1). Reference has also been made in the literature to its application to the built heritage $[43,44]$ and even to a Medieval bridge [45].

Whilst BIM methodology is not compulsory in Europe, in 2014 the European Parliament enacted Directive 2014/24/EU providing that member countries may require BIM methodology in tenders for publicly funded construction. In Spain that directive was transposed into domestic law under Royal Decree 1515/2018, which created an inter-ministerial commission on using BIM methodology in public procurement. In parallel, a Building SMART Spanish Chapter working group ('Legend-HBIM', a not-for-profit association) was established to apply the method to the cultural heritage and was tasked with adapting BIM to the particulars that distinguish the built heritage from contemporary architecture.

The aim of the methodology described and its scope consist in developing a digital 3D model for public works at a minimum cost in support of the subsequent creation of an HBIM. The steps to be followed to that end are set out in $[46,47]$.

The novelty of the methodological proposal and the interest it holds revolve around the inexpensive, open-access modelling (using free tools) involved. The outcome is ready public access to information on a given cultural asset, redounding to its value enhancement, stricter protection and the allocation of funding for a more comprehensive HBIM.

\subsection{Disseminating the Digitised Heritage}

Whereas dissemination of heritage assets through a series of photographs or drawings continues to be widespread, determining how 3D tools and technologies can create much more powerful resources is an area well worth exploring.

Virtual heritage is defined by Stone and Ojika [48] as "the use of computer-based interactive technologies to record, preserve, or recreate artefacts, sites, and actors of historic, artistic, religious, and cultural significance and to deliver the results openly to a global audience in such a way as to provide formative educational experiences through electronic manipulation of time and space".

Ready accessibility is clearly a determinant in the success or failure of digitised heritage dissemination. In 3D modelling, the use of standard open-source formats such as ISO-approved X3D (.x3d) is recommended to ensure universal access and digital conservation [49]. X3D is used much less widely for the electronic dissemination of 3D models than file formats such as Wavefront (.obj), Universal 3D (.u3d) and Collada (.dae), however.

Although all the aforementioned formats call for specific software even to simply view the files, Adobe PDF3D holds promise as a pdf-like vehicle with which to open, view and interactively move 3D model files. Its advantage over other formats is that it is so widespread for exchanging all manner of documents that a substantial proportion of 
users will be able to readily access the respective files. In addition, pdf files with threedimensional information can be uploaded to traditional platforms or websites with no need for major changes to those vehicles [50] (p. 1).

Today, most 3D models used for heritage are viewed from free web repositories such as Sketchfab, p3d.in, Smithsonian X3D and Google Poly [51]. Nonetheless, alternatives to such repositories also exist, such as 3DHOP (3D Heritage Online Presenter), an opensource software for creating high-resolution, interactive web presentations for $3 \mathrm{D}$ heritage models [52].

Built heritage (such as public works) dissemination initiatives must bear in mind the geographic and territorial dimension of such structures. In that regard KMZ is a promising free format that enables users to share, access, view and consult digitised models and their surrounds with Google Earth. The chief advantage to using that format and software is that searches are speedy, intuitive and visually attractive for users with no prior experience with databases or GIS.

Three-dimensional model-mediated cultural heritage dissemination is rapidly expanding its frontiers, with the latest advances stemming from research on so-called immersive technologies such as augmented (AR), virtual (VR) and mixed (MxR) reality. Hosts of examples of that trend can be found in the application and use of VR/AR in museums and exhibitions [53] or educational environments [54].

In addition to the foregoing, 3D printing has immense potential for conserving, disseminating, restoring and accessing the cultural heritage. The ability to stimulate the senses with ever-more detailed printouts enhances mere digital viewing. Three-dimensional printing is consequently one of the most effective tools in areas such as heritage education [55], dissemination [56] and conservation [57].

Despite the bevy of articles and research papers on 3D model-based heritage capture and dissemination, detailed methodology enabling non-expert users on a low budget to digitise, share and view 3D heritage content is very hard to come by.

This article describes a 3D digitisation and visualisation methodology for cultural heritage assets based primarily on the use of free, open-source software and web services, wherever possible. The procedure described is illustrated with a case study of Ariza Bridge, a sixteenth century Renaissance-style structure partially restored in the nineteenth century. Authored by Spanish architect Andrés de Vandelvira, it is sited in Úbeda in the Spanish province of Jaén. Despite its cultural asset listing, it was flooded by the Giribaile reservoir waters in 1998 and is only visible in full during droughts.

\section{Methodology}

The approach adopted here proposes a procedure for the sustainable study and dissemination of the public works heritage (Figure 1). The first step, the drone-mediated aerial capture of a sizeable heritage asset, is followed by SfM (structure from motion) 3D digitisation, model optimisation for dissemination via online repositories, $A R$, holographic visualisation and 3D printouts of the model. The proposal is based in its entirety on the use of free software and low-cost tools.

\subsection{SfM Photogrammetric Restitution}

Structure from motion (SfM) is a high-resolution photogrammetric method that carries a much lower price tag than other $3 \mathrm{D}$ restitution techniques. While borrowing from photogrammetry, SfM is a tool developed in the world of artificial vision to build 3D models from unstructured, non-calibrated images whose orientations and deformities are resolved computationally [58] to deliver a more versatile and robust strategy. Today, photogrammetry and SfM are combined in the software that supports this type of task.

\subsubsection{Image Capture}

Photogrammetry is the discipline that studies the geometric properties of objects or settings and their spatial characteristics based on photographs. The distinctive feature of 
the technique is that whereas photography represents only two-dimensional attributes, photogrammetry works with three-dimensional information sourced from a series of overlapping two-dimensional images. The overlaps identify common points used to re-create $3 \mathrm{D}$ views.

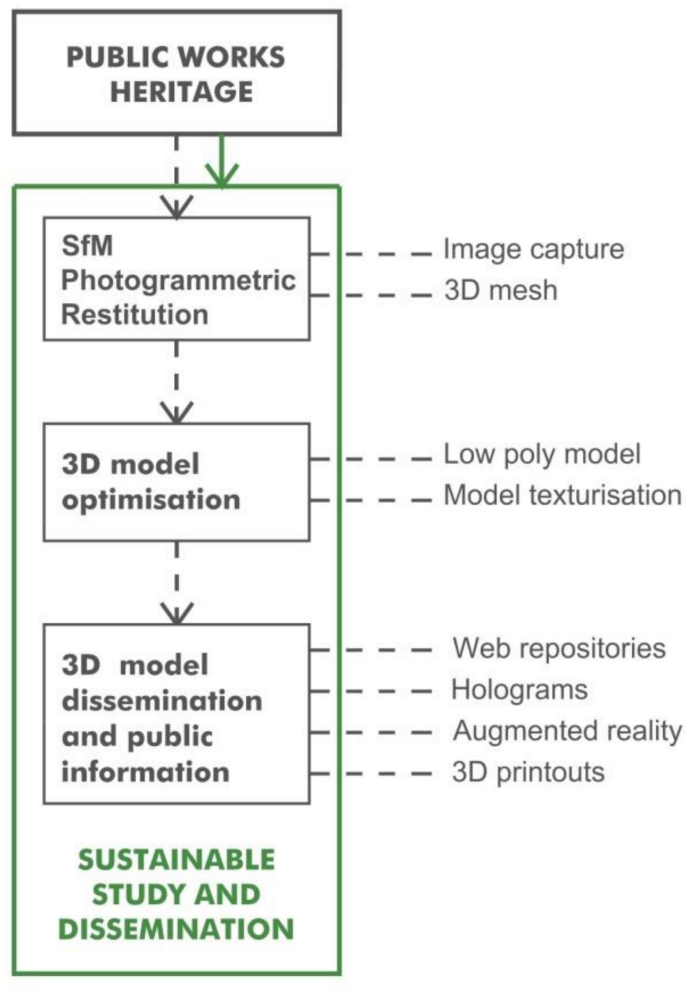

Figure 1. Flowchart of the sustainable methodology used in public works heritage dissemination, furtherance of understanding and value enhancement.

Today's image-based 3D restitution software determines the geometric properties of objects from non-calibrated photographs, a process that entails comparing reference points or pixel concurrences in a series of photographs. That in turn calls for a certain quality and number of photographs to correctly process, combine and triangulate the data to generate a $3 \mathrm{D}$ point cloud.

The choice of the survey instruments and methodology to be used and the quality of the 3D model generated depend heavily on the aims pursued and the setting and characteristics of the object studied. Parameters such as object geometry or material characteristics are imperative to reliable results.

\subsubsection{Three-Dimensional Mesh}

A wide variety of SfM-based 3D modelling software is available, from free programs such as VisualSFM and Regard3D to professional for-profit products such as 3DF Zephyr, AgisoftMetashape, 3D SOM and Reality Capture. Recent studies such as those published by Gagliolo et al. [59] and Rahaman and Champion [60], comparing the quality and accuracy of the point clouds generated by free and commercial photogrammetric software, have concluded that they are of nearly the same quality.

The procedure for generating a 3D model consists in four main stages: (1) Image entry, automatic orientation of stereoscopic pairs to generate a scattered point cloud; (2) densification, construction of a dense point cloud; (3) mesh creation; and (4) application of texture.

Following these stages, a particular application is developed with specific software in the case study in the next section. 


\subsection{Three-Dimensional Model Optimisation}

Three-dimensional model optimisation is conditioned by file size, a key factor in web dissemination. Models created from a photogrammetric or laser scan survey may comprise from a few thousand to several million polygons, with a direct impact on file size (MB or GB). In heritage 3D models designed for viewing on web platforms or mobile devices, a balance between size and resolution is of cardinal importance [61] (p. 215).

The usual procedure consists in combining very light (retopologically simplified) meshes with high quality photographic textures and ordinary maps to offset the optimisationmediated loss of model detail. Retopology-based optimisation is widespread in photogrammetric, sculpted or any other type of 3D modelling where use and editing are awkward due to the large numbers of polygons or very irregular meshes involved. Digital representation technologies such as augmented or virtual reality also call for optimised models.

Before optimising a model its purpose must be defined. Is it meant for dissemination or for exclusively scientific purposes? Does it represent a painting, which would require high quality texture but less rigorous geometry, or an object with a solid colour surface in which texture is of minor concern but geometric perfection imperative? As a general rule, the recommendation is to work with the highest possible quality while optimising the model in keeping with the needs at issue.

\subsubsection{Low Poly Model}

Low poly models can be generated with simple visual design software that delivers output similar to automatic retopology by rapidly processing non-complex models. The result is a low poly, smooth topology model consisting wholly in quads.

\subsubsection{Model Texturisation}

Model texturisation, also called 'baking', consists in extracting colour and relief attributes from a map of a high poly model for subsequent application to a low poly model to recover the properties lost during optimisation.

The result is a lightweight optimised model apt for use in many visualisation environments.

\subsection{Dissemination 3D Model}

New technologies are acquiring a predominant role in heritage dissemination, for they enable audiences the world over to access cultural assets with a wide spectrum of applications. That, however, poses other problems: a surfeit of web information may be confusing; 3D model validation systems are insufficiently visible; user access to the scientific and historical documents that endorse the validity of virtual re-creation premises must be enhanced; and the constant change in digital media and formats calls for ceaseless updating of information storage and dissemination formulas [62].

The following is a description of the procedure followed to disseminate the 3D model of Ariza Bridge using a number of accessible web platforms and low-cost tools.

\subsubsection{Web Repositories}

Most recent online projects for the 3D dissemination of the cultural heritage such as EUROPEANA, Atalaya 3D [63] and 3D-ICONS [64] use web repositories to publish interactive content [65]. The process is similar in all of them. Once the user's account is created, it is allowed to upload 3D content, adjusting to the repository criteria, in order to distribute it. Three-dimensional content can be uploaded, according to the repository criteria, to be distributed, for free or for payment, according to the user's wish. Once the models are uploaded, anyone can download them and freely use them. They thus become a form of diffusion of models and 3D culture at an international level and with great acceptance by the whole 3D community.

Any number of 3D repositories are in place, although Sketchfab is the platform most widely used by institutions and museums to display their digitised models. The 
success and enormous potential of the free version as a dissemination vehicle, despite its limitations, are attributable to its user interface tools, ease of use, reliability and graphic quality. In addition, it is endorsed by studies on 3D web applications such as conducted by Guidazzoli et al. [66]. Nonetheless, since Sketchfab, like other popular online platforms, was not explicitly designed for heritage storage and dissemination, the assets are often presented completely out of context [67].

\subsubsection{Holograms}

Holography was invented in 1948 by Hungarian physicist Dennis Gaboren. This is an advanced photographic technique that consists in creating whole objects from threedimensional images, enabling viewers to see the object from different angles as they circle the hologram. The use of one or another of the various techniques for obtaining holographic effects depends on the intended application, as explained in Svoboda et al.'s introduction to the basics of the technique [68].

Professional 3D image projectors are presently available on the market, but scantly affordable. In contrast, simple, low-cost options are in place to build holographic viewers. The idea is to build a reflective pyramid, a fundamental element in holographic projection, with no need to use costly or special materials to create the optical effect of a 3D model that floats in thin air. The technique used is Gaussian optics on a reflective material [69]. The three stages involved in generating the end hologram are: building the holographic pyramid; editing the video to be projected; and viewing the hologram.

a. Holographic pyramid. The pyramid and the structure underlying holographic systems can be made of materials such as glass, methacrylate or acetate.

b. Video editing. A video is generated in which the left, right, front and rear views of the 3D model are viewed simultaneously so the three-dimensional optical effect can be correctly viewed when projected on the screen.

c. Viewing the hologram. The final hologram is viewed by setting the pyramid upsidedown on the screen and projecting the video.

\subsubsection{Augmented Reality}

Augmented reality is a powerful tool sufficiently versatile to be used across a wide range of applications in different areas of endeavour, cultural heritage among them. In this technique the virtual is superimposed on the real world such that the user's view of the latter is 'augmented' with simultaneous, computer-generated virtual content [70] (p. 213). Thanks to the universal presence of tablets and smart phones with mobile screens and cameras, such images can be viewed anytime, anywhere by non-experts.

\subsubsection{Three-Dimensional Printouts}

Although historically this technique was developed to lower the costs of producing industrial prototypes, with its countless potential uses it has been widely adopted for architectural and heritage dissemination purposes. The reason is that scale models of buildings or replicas of heritage assets can be 3D printed much faster and at a much lower cost than using traditional methods.

Obtaining a 3D-printed scale model has a dual purpose: on the one hand it serves as a working tool for studying the element and on the other it generates educational material which, together with other resources, heightens awareness of the heritage from new perspectives.

Unlike other dissemination tools, 3D printing does not call for model optimisation, which might even prove to be counterproductive. Three-dimensional printing can be broken down into three stages.

a. Verification of the 3D model. Three important, along with other minor factors, must be borne in mind before printing a model. First, the model must be air-tight, i.e., the mesh should have no gaps. Second, the mesh thickness must be defined and monitored from outside in, for objects with no thickness cannot be printed. Third, 
when the model is converted to an STL file, the tolerance or the difference between the original form and the new format must be established. The standard tolerance of $0.01 \mathrm{~mm}$ may vary depending on the 3D printer.

b. From .STL format to G-CODE. Once the model is prepared and the .STL file (standard triangle language, a computer-aided design (CAD) format that defines 3D object geometry, excluding information on colour, texture and physical properties) is generated, a G-CODE must be produced, consisting in numerical control instructions whose lines guide the printer as it builds the piece. Free printing software such as Cura [71], Slic3r [72] and Repetier [73] can be used for this purpose.

c. Final printout. Many printing techniques are in place, such as fused deposition modelling (FDM), stereolithography (SLA), digital light processing (DLP), selective laser sintering and so on.

\section{Results: Case Study of Ariza Bridge}

The steps set out in the methodology were followed in the case study described hereunder to illustrate some of the procedures involved and the problems posed. Ariza Bridge, sited at Úbeda, Spain, was chosen for the study as it was deemed representative of the country's public works heritage. A sixteenth-century Renaissance stone arch bridge, it is one of the several long-span masonry bridges built in that period in northern Andalusia, a region in southern Spain. It features five barrel vaults, a $31 \mathrm{~m}$ central span and a double arch ring. Commissioned and paid for by the bishopric, it was built between 1550 and 1560 according to the records left by architect and master builder Andrés de Vandelvira, who also designed Jaén Cathedral. It spans the River Guadalimar on the road from Úbeda to La Carolina [74,75]. It was originally sloped with parapets and semi-circular piers downstream and triangular cutwaters. Repairs conducted in 1868 involved an unfortunate reconstruction of the cutwaters and downstream pier faces, however, while also lowering the (nonetheless still perceptible) hump-back. A second vault under one of the side vaults was added in the 1980s, offsetting the sideways thrust of the $5.6 \mathrm{~m}$ to $9.5 \mathrm{~m}$ wide piers to balance the structure [76].

This particular bridge was chosen not only on the grounds of its undeniable cultural heritage value, listed as an Asset of Cultural Interest (BIC) by the Andalusian Institute of Historical Heritage (IAPH), but also because it is deemed to be at special risk. Since 1998, when the Giribaile reservoir became operational and a new longer bridge was built at a higher elevation, the older bridge was decommissioned and allowed to sink below the reservoir's high water mark. Before 1997 when the reservoir was filled, the authorities planned to relocate Ariza Bridge stone by stone at a site $10 \mathrm{~km}$ north of La Loma, a town near Nuestra Señora de Guadalupe Chapel. As that project was never implemented, however, today the bridge is only partially or wholly visible during droughts. It was first seen to emerge in February 2010 and on several occasions thereafter, including April 2019 when the images for this case study were captured.

The bridge has been 'red-listed', i.e., officially identified as a heritage element at risk of disappearance, destruction or essential alteration in an attempt to bring public attention to the situation and endorse the need for strengthening or restoration [77]. The conditions prevailing today will clearly induce deterioration of this valuable historic structure, whilst the perceptible detachment of some of its components may well lead to its collapse. The present study was undertaken to alert public opinion to the plight of the bridge and secure support for its protection

\subsection{SfM Photogrammetric Restitution \\ 3.1.1. Image Capture}

The first step in the method consists in drone-mediated image capture. In the case study, the data were collected with a DJI Spar drone able to cover the entire bridge. The $300 \mathrm{~g}$ UAV used featured a maximum flying speed of $50 \mathrm{~m} / \mathrm{s}$ and maximum elevation of $4000 \mathrm{~m}$ above sea level. Powered by $15 \mathrm{~min}$ smart flight batteries, it carried a built-in 1/2.3 
12 MP CMOS camera with a $35 \mathrm{~mm}$ equivalent lens and was fitted with GPS positioning and recording facilities.

After verifying the weather and wind, the drone was flown on 15 April 2019, a slightly cloudy day when air velocity was $<6 \mathrm{~m} / \mathrm{s}$, i.e., highly favourable conditions that ensured focused, uniformly lit photographs of the bridge unaffected by dark shading. After calibrating the geo-referencing and other instruments, the drone was flown in manual control mode at a height never more than $50 \mathrm{~m}$ above the bridge. Two $15 \mathrm{~min}$ flights and a total of 159 photos were required to cover the entire $100 \mathrm{~m}$ long structure (Figure 2).

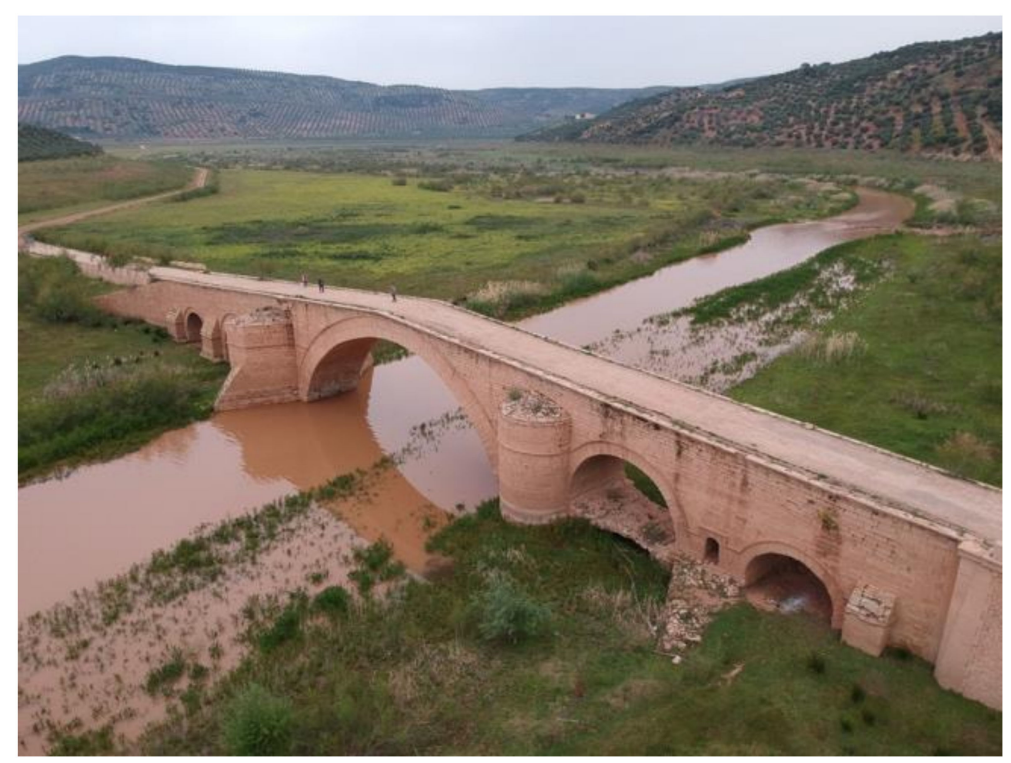

Figure 2. Aerial photograph of Ariza Bridge taken with a DJI Spark drone, 15 April 2019.

\subsubsection{Three-Dimensional Mesh}

Inasmuch as the aim of this study is the visualisation of the cultural heritage with a 3D model generated at low cost, Regard3D, a free, easy-to-use photogrammetric restitution software, was used. Although it features no point cloud or mesh edition tools, Regard3D does include surface reconstruction and texturing functions.

The three-dimensional model was generated in keeping with the four main stages specified earlier and described more fully below.

1. Image entry. After the 159 photographs needed to cover the entire bridge studied here were entered into the application, Regard3D displayed the metadata for the photographs on the screen.

- Feature and concurrence detection. This step identifies the key points in each image and their concurrence in the entire set of photos. As changing the default settings may have substantial effects on computing times, it is not recommended.

- Triangulation. The following step, triangulation, consists in positioning the key points detected in the preceding step in three dimensions. At the end of the process, the results, the most important of which is 'Cameras calibrated/total', are displayed in a pop-up window showing whether all the photos in the set were used. The three-dimensional scattered point cloud can be seen in the 3D viewer.

2. Densification. Point clouds are a set of points containing dimensional, geometric, and colorimetric information. As the cloud delivered in step 1 is scattered, i.e., contains only the concurrent key points in the photo set, the object or scene is scantly recognisable. Densification yields a high-density, highly accurate point cloud, in this case for the bridge studied (Figure 3). The point cloud must be processed and discretised before generating the mesh to lower noise and delete non-valid points, which may generate undesired effects during subsequent mesh creation. Since Re- 
gard3D software does not feature editing tools, the point cloud must be exported to MeshLab [78], a free, open-source software that delivers a mesh based on the Regard3D-generated point cloud. The imported point cloud must then be cleansed of noise, atypical values and irrelevant points with tools furnished by MeshLab for point selection and elimination. The initial point cloud (outcome of the photogrammetric survey) generated here weighed $43.8 \mathrm{MB}$ and comprised 1,703,874 points. For it to be usable, however, the scope of the work had to be delimited. As here it was defined to comprise the bridge and its closest surroundings, the cloud ultimately used contained $1,154,940$ points and weighed 33.9 MB.

3. Mesh creation. A mesh is a discrete representation of a geometric model based on its geometry, typology and associated attributes [79]. The MeshLab algorithm triangulates a point cloud using its vertices to convert it into a tri-based structure or triangular mesh. The triangulation systems used by the software include the Delaunay procedure, the ball point pivoting algorithm, and the marching cube algorithm, along with Poisson surface reconstruction, a particularly favourable approach, for it consistently delivered dense, smooth reconstructed surfaces [80] (p. 6)

4. Application of texture. Texturing is the operation in which 3D models are afforded a skin, and virtual objects a real appearance. Texture is introduced by automatic orientation and rectification of each photo adapted to the model from its vantage point. The result is a texture map which more often than not is confusing, for the texture cannot be matched with the naked eye to the parts comprising the model (Figure 4). During subsequent optimisation, the texture is oriented by a process known as baking. The texturised 3D model obtained is optimised prior to entry in dissemination tools with 3D image modelling and edition software such as InstantMeshes [76] and Blender [81] to reduce model size for readier handling.

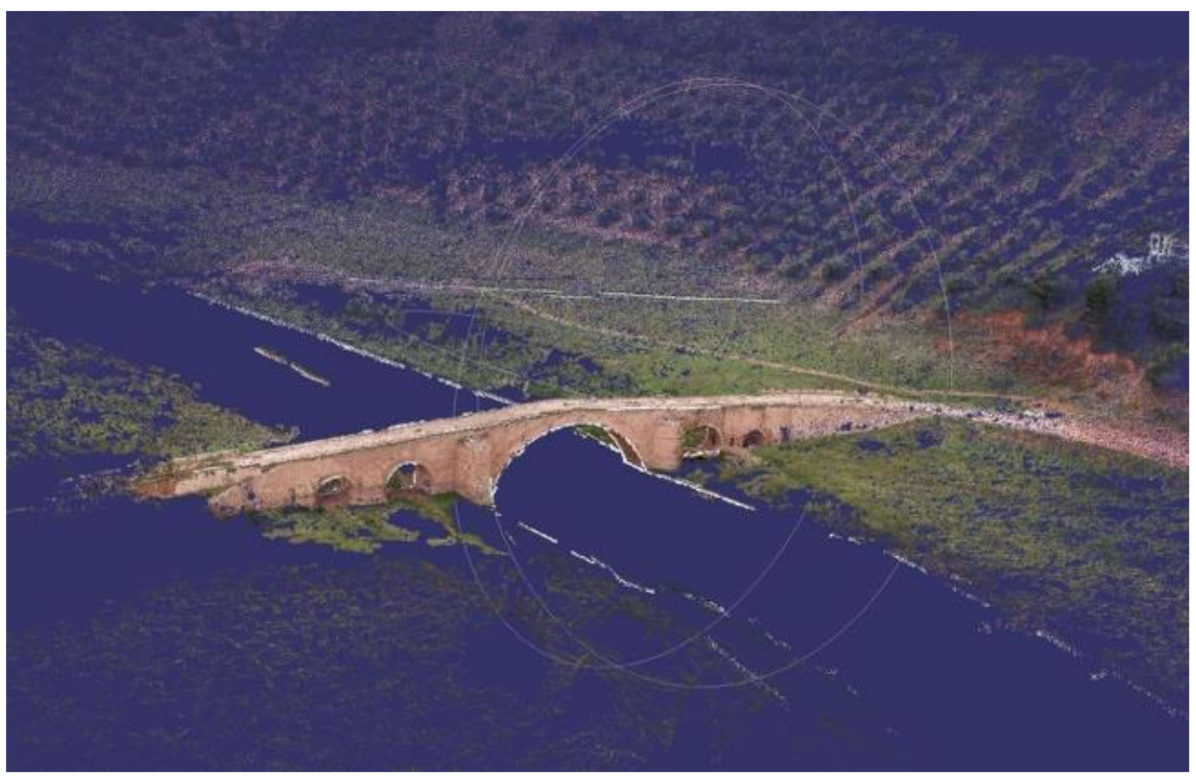

Figure 3. Overview of Ariza Bridge: dense point cloud generated with Regard3D and edited with MeshLab software.

\subsection{Three-Dimensional Model Optimisation}

The 'high poly' (so called in allusion to the polygonal weight of the constituent mesh) or photogrammetric model of Ariza Bridge had to be reduced in a simple, two-stage process consisting of: (a) 'low poly' model generation and (b) model texturisation.

The initial triangulation using the non-optimised 3D model yielded a total of 155,026 facets, subsequently brought down to 29,194 in the optimised model. The former weighed $10.7 \mathrm{MB}$ and the latter $6.2 \mathrm{MB}$. 


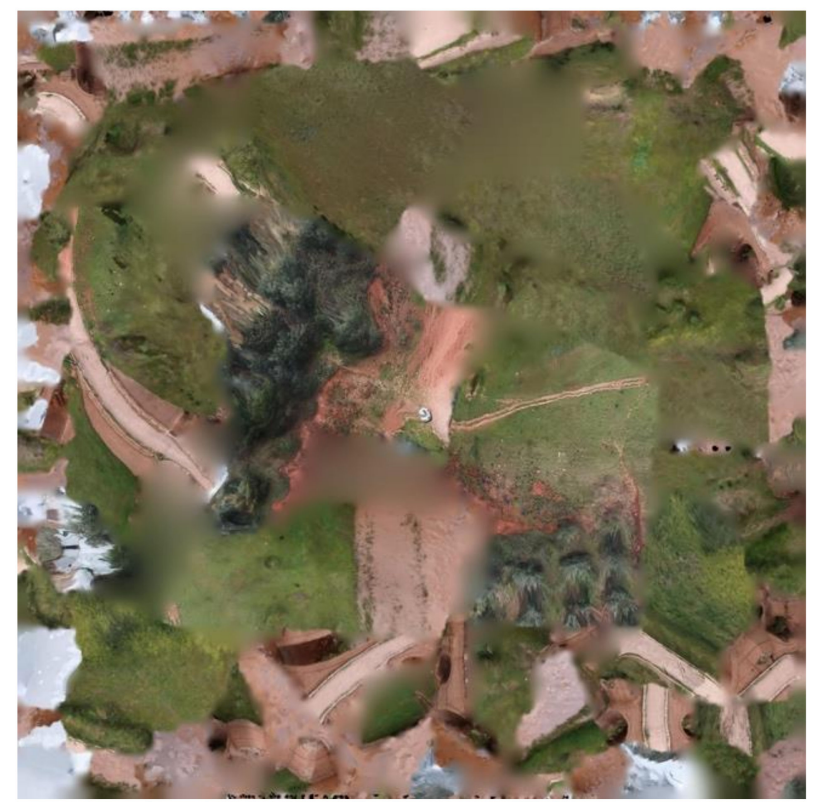

Figure 4. Texture map of the model generated automatically by Regard3D.

\subsubsection{Low Poly Model}

Instant Meshes software generates low poly models with a simple visual design. The resulting models retain the basic geometry of the high poly photogrammetric model but forfeits many of the details as well as the original photographic texture (Figure 5).

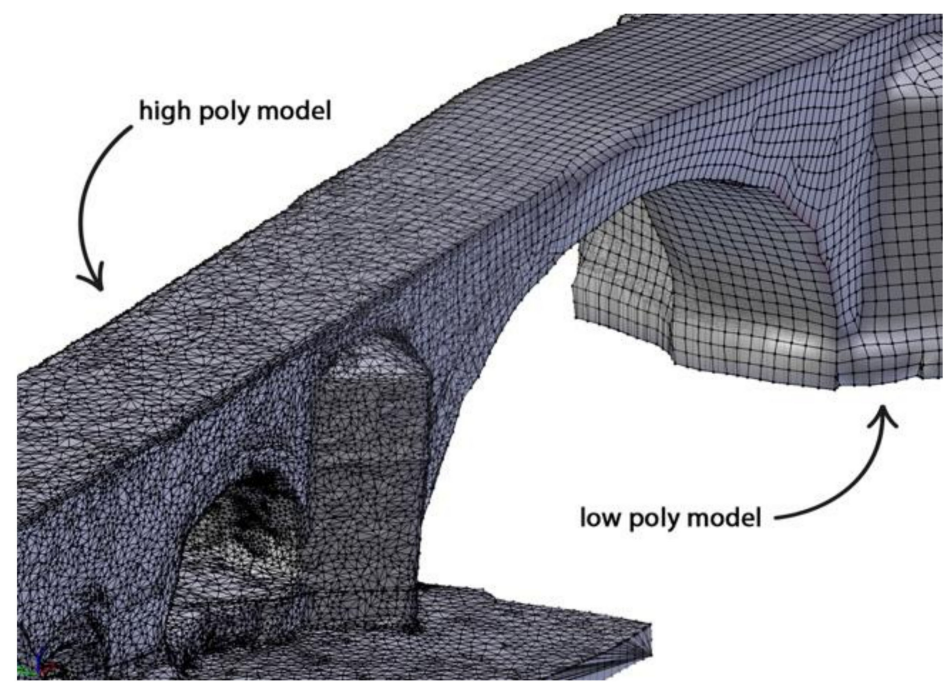

Figure 5. Instant Meshes optimisation of the Ariza Bridge model.

\subsubsection{Model Texturisation}

In our case, the 'baking' procedures used in texturisation were run on Blender, a free, open-source 3D computer graphics software [82].

The visible result delivered by the optimised model exhibited the same colour, texture and details as the original photogrammetric model (Figure 6).

\subsection{Three-Dimensional Model Dissemination}

\subsubsection{Web Repositories}

Uploaded to the Thingiverse web repository (Digital Designs for Physical Objects), the Ariza Bridge model can be downloaded from https:/ / www.thingiverse.com/thing:4957849 (accesed on 29 July 2021). 


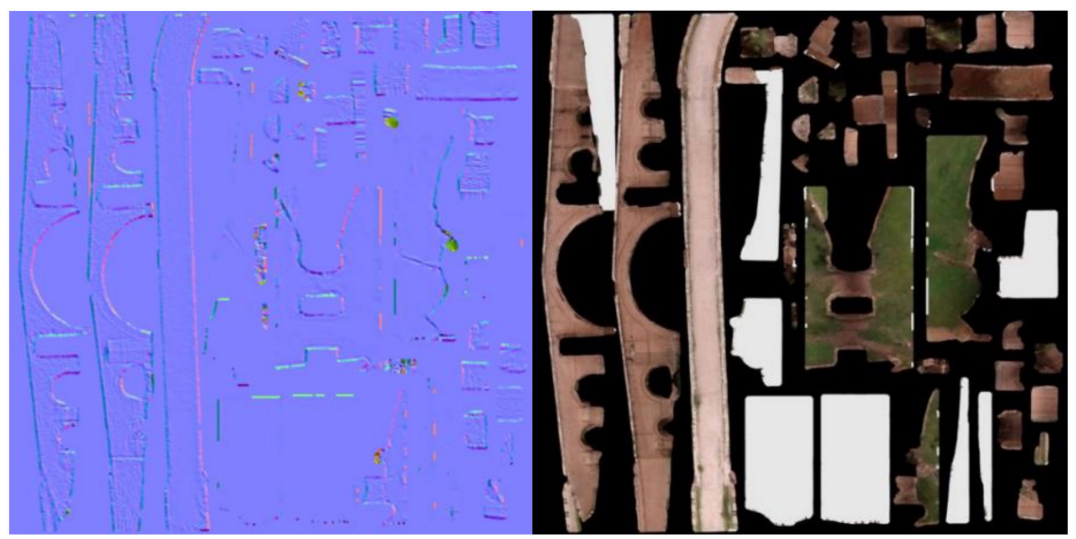

Figure 6. New Blender-textured and normal maps of Ariza Bridge.

\subsubsection{Hologram}

In our case, the steps described in the methodology were followed with particular procedures:

- Holographic pyramid. Acetate, a semi-soft, transparent plastic, was used in the present case study. The four sides of the pyramid were cut to a size in keeping with the screen used. For tablet-like screens the trapezoids have a $12 \mathrm{~cm}$ long base, a $2 \mathrm{~cm}$ short base and a height of $7.5 \mathrm{~cm}$ [83]. When pasted together at the sides the four identical trapezoids formed a truncated pyramid pitched at a $45^{\circ}$ angle with the screen, ensuring that the video projected would be visualised as a perfectly vertical, deformation-free hologram.

- Video editing. Open Shot free, an open-source video editor, was used in this step [84].

- Viewing the hologram. The pyramid was then positioned upside-down on the screen while projecting the video with the lights dimmed to enhance visibility (Figure 7).

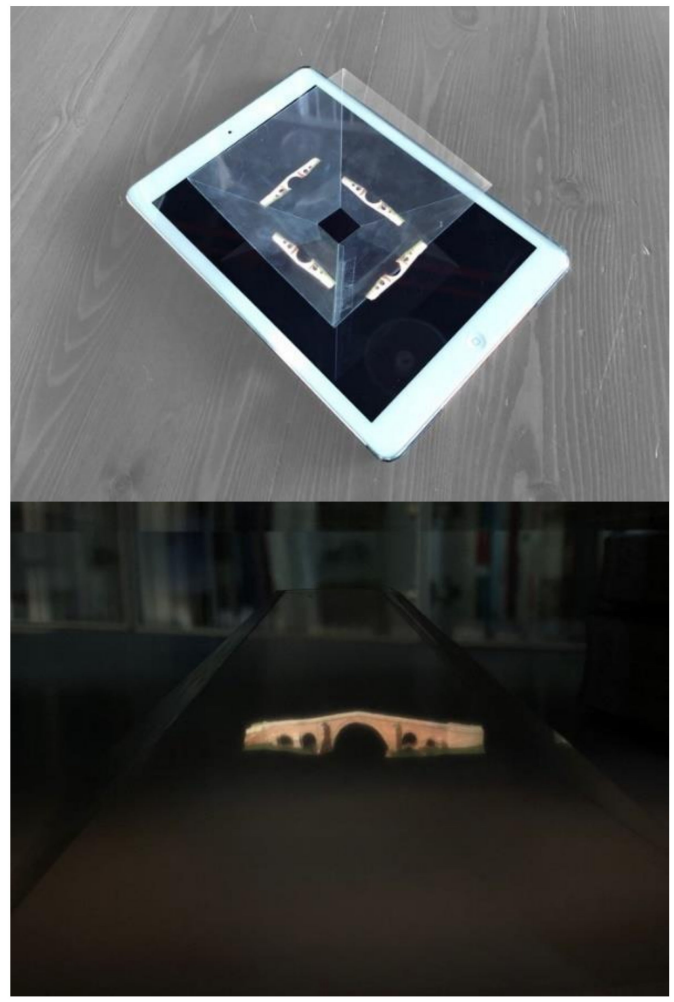

Figure 7. Ariza Bridge hologram generated with an inverted pyramid. 


\subsubsection{Augmented Reality}

A number of media presently support AR and VR model visualisation. The in-house methodologies developed by some studios [85] call for a command of the skills needed to use AR software such as ARToolKit, a significant drawback. Others endorse the use of resources that promise to be universally applicable. The Sketchfab platform is one example. In addition to affording online model storage and viewing, it features immersive experiences with 3D models in VR and AR with its $3 \mathrm{D}$ viewer, which is compatible with most operating systems (Windows, Max, Linux, iOS and Android) [86]. Sketchfab must be installed on a compatible mobile device to view models in both VR and AR (Figure 8). VR viewing calls for HMD accessories such as Vive, Rift, Gear VR or sheets of cardboard.

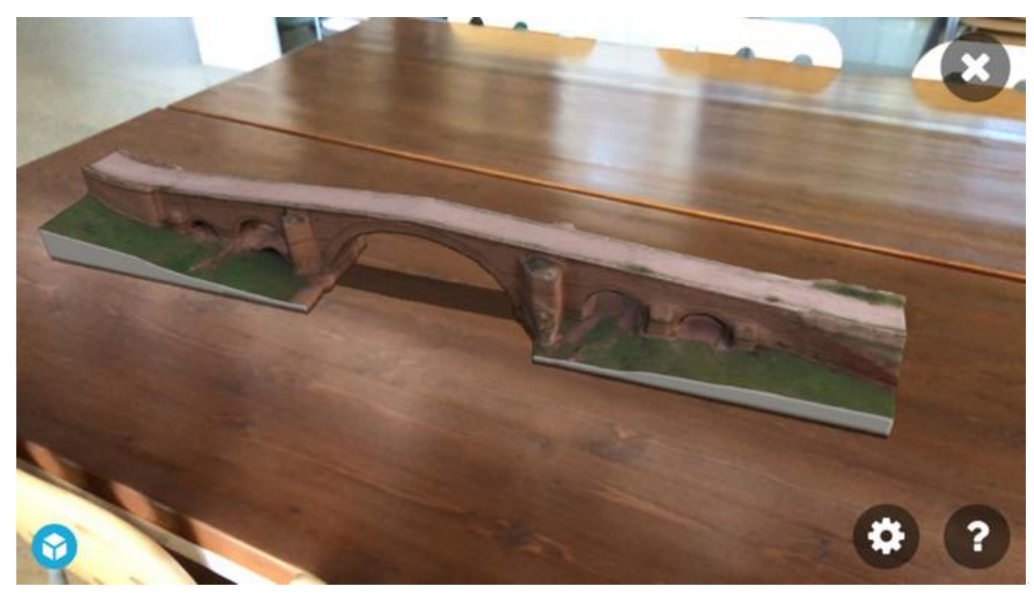

Figure 8. AR view of Ariza Bridge using Sketchfab.

\subsubsection{Prints 3D}

In the present case study, the model was printed with a Creality Ender 3 FDM printer fitted with a polylactic acid (PLA) filament, delivering layer resolution of $0.17 \mathrm{~mm}$ at a speed of $25 \mathrm{~mm} / \mathrm{s}$. The total print time was $4 \mathrm{~h}$ and $35 \mathrm{~min}$.

The result was a 1:625 (maximum) scale model (Figure 9). The limits to the size of the printed object depend not only on the printer's maximum print volume, but also on model proportions. Since in this case the object was long and narrow, a larger model would call for printing by subsequently assembled sections.

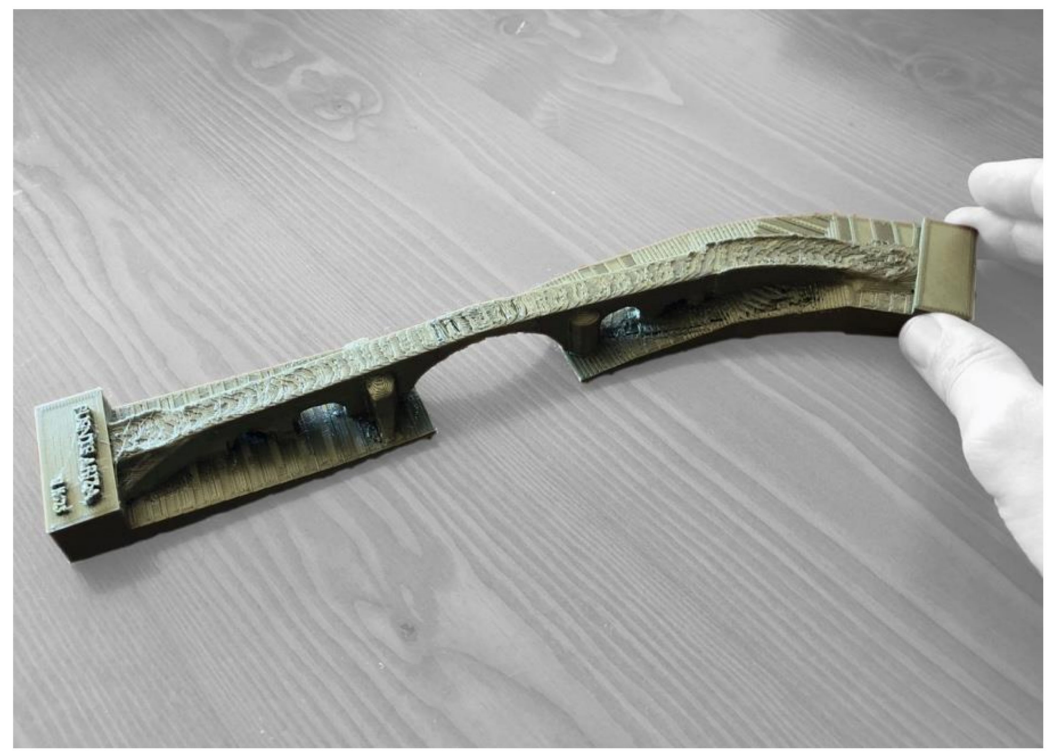

Figure 9. Three-dimensional printout of Ariza Bridge with a Creality Ender 3 FDM printer (scale: 1:625). 


\section{Discussion}

To facilitate discussion and tracking, Table 1 summarises the set of stages, steps and sub-steps, identifying the processes involved and the software used.

Table 1. Stages and procedures involved in civil works heritage digitisation, optimisation and dissemination $\left({ }^{1}\right.$ free, open-source software).

\begin{tabular}{|c|c|c|c|c|c|}
\hline Stage & Step & Sub-Step & Process & Software $^{1}$ & References \\
\hline \multirow{5}{*}{ SfM } & Image capture & & Photogrammetry & & - \\
\hline & \multirow{4}{*}{ 3D mesh } & Imageentry & Stereoscopicpairs & VisualSFM, Regard3D & - \\
\hline & & Densification & Dense pointcloud & MeshLab & {$[37,78]$} \\
\hline & & Meshcreation & Triangulation & & {$[79,82]$} \\
\hline & & Texturing & Texturing & InstantMeshes, Blender & {$[81,82]$} \\
\hline \multirow{2}{*}{ 3D model } & Low poly & & Topologicalisation & InstantMeshes & [81] \\
\hline & Model texturisation & & Baking & & - \\
\hline \multirow{6}{*}{ Dissemination } & Web repositories & & Georeferencing & Sketchfab & [67] \\
\hline & & Holographic pyramid & 3D screens & & [83] \\
\hline & Holograms & Video editing & Video edition & OpenShot & [84] \\
\hline & & Viewing the hologram & Video projection & & [68] \\
\hline & Augmented reality & & Virtual vision & Sketchfab & {$[85,86]$} \\
\hline & $3 \mathrm{D}$ prints & & Scale model & & - \\
\hline
\end{tabular}

Several recommendations may be gleaned from the methodology described. The first factor to bear in mind when surveying an asset is the need for good imaging, for the fewer the subsequent amendments to the model needed (gaps or poor texture), the better.

If the model is intended for research a raw or high poly model is required, for the only processes allowed in such cases are scaling and geo-referencing. Whether or not the computer used is powerful enough to work with high poly models, a copy of the original should always be saved.

For models designed for dissemination, retopological techniques should be used to optimise the high poly mesh surface for subsequent modification as necessary. After UV-mapping, the texture is baked onto the resulting low poly model. If the model is to be $3 \mathrm{D}$ printed, however, the high poly model may be scaled and modified (closing gaps, creating a platform as needed and so on) with no need for retopology, for in such cases retaining the highest geometric quality is of utmost importance. Texture, in contrast, is normally irrelevant for, at this writing at least, the vast majority of commercial 3D printers do not print in colour.

The novelty of the present proposal lies in its definition of a sustainable, accessible method as a low-cost tool to model the built heritage. Such a tool may be particularly well suited to public works and make yet another contribution to the complex process of furthering the understanding of and disseminating their cultural heritage value.

The process shows how low-cost tools can be used to document the geometric and visual configuration of the work. Its sustainability contributes to enhancing the value of the cultural heritage and its dissemination, thereby favouring its protection and management. In light of the prominence of the territorial dimension of the public works heritage, the method features geo-referencing to identify a given work with its location. This proposal allows the usage of digital technologies towards enhancing sustainability. The methodology can be sustainably applied to other types of built heritage elements or objects whose physical and material characteristics are susceptible to digitisation, optimisation and dissemination.

Digital technologies and digital transformation offer a wide array of opportunities for value creation, but this process must be guided by the knowledge management of the organisations involved [35]. 


\section{Conclusions}

As discussed throughout the article, new technologies are playing a growing part in heritage research, conservation, and dissemination, for the many tools and applications developed are apt for documenting and furthering the universal accessibility of cultural content. Many of the methodologies and tools in question are inaccessible to large swathes of the population, however, either because they call for very costly professional equipment and commercial software or because the modus operandi for achieving good results is poorly defined. This article aimed to clearly and simply describe the procedures involved. The idea is to enable non-expert users such as small museums, heritage institutions and local groups to digitise, share, view and even 3D print their collections with no need for major budgetary outlays or extensive training in photogrammetry, modelling or programming.

With the use of interactive computer-based technologies the built heritage can be inventoried, conserved, or recreated and the geo-referenced results made accessible to a global audience. As the cultural heritage is a common good shared by all of humanity, it must be preserved for future generations. Low-cost, open-source digital technologies, in conjunction with the methodology described here, can be deployed to institute sustainable cultural heritage management and value enhancement strategies.

Author Contributions: S.P.-S. wrote the Methods and Results sections; P.H.-L. wrote the Abstract and Introduction; J.B.-L. drafted the article outline and acted as task coordinator; B.C.-A. drew the illustrations and arranged the References; and J.A.M.-C. reviewed, annotated and made recommendations on the draft version of the paper. All authors contributed to the conception and design of the research conducted and the applications developed. All authors have read and agreed to the published version of the manuscript.

Funding: This research received no external funding.

Institutional Review Board Statement: Not applicable.

Informed Consent Statement: Not applicable.

Data Availability Statement: The study did not report any data.

Acknowledgments: The support and in-house funding received from Fundación Miguel Aguiló are gratefully acknowledged.

Conflicts of Interest: The authors declare no conflict of interest.

\section{References}

1. Hernández Lamas, P.; Beatriz, C.A.; de Castro Cuartero, O.; Bernabéu Larena, J. Mobile Applications, Geolocation and Information Technologies for the Study and Communication of the Heritage Value of Public Works. Sustainability 2021, 13, 2083. [CrossRef]

2. Riegl, A. El Culto Moderno a Los Monumentos. Caracteres y Origen; Visor: Madrid, Spain, 1987.

3. Martínez Vázquez de Parga, R. El patrimonio de las obras públicas. Revista Obras Públicas Colegio Ingenieros Caminos Canales Puertos 2003, 3, 79-82. Available online: http:/ /ropdigital.ciccp.es/revista_op/detalle_articulo.php?registro=18359\&numero_ revista $=3438 \&$ anio $=2003$ (accessed on 20 October 2021).

4. Cruz, L. Plan Nacional de Patrimonio Industrial; Instituto del Patrimonio Cultural de, España, Ed.; Ministerio de Educación, Cultura y Deporte: Madrid, Spain, 2016. Available online: https:/ /www.culturaydeporte.gob.es/planes-nacionales/dam/jcr: eba404cd-e170-419d-b46a-e241ebd1b1b0/04-texto-2016-pnpi-plan-y-anexos.pdf (accessed on 23 November 2021).

5. Carrión, A.; Cruz, L. Plan Nacional de Paisaje Cultural; Instituto del Patrimonio Cultural de España, Ministerio de Educación, Cultura y Deporte: Madrid, Spain, 2015. Available online: http://www.mecd.gob.es/planes-nacionales/eu/dam/jcr:55b779f7-0 37f-45a0-baa0-17f27bc2587a/05-maquetado-paisaje-cultural.pdf (accessed on 11 September 2021).

6. Fernández-Ordoñez, J.A. Obras Públicas y Monumentos. Rev. Obras Públicas Col. Ing. Caminos Canales Puertos 1995, $3347,7-13$.

7. Aguiló, M. Qué Significa Construir: Claves Conceptuales De La Ingeniería Civil; Abada: Madrid, Spain, 2013.

8. Aguilar, I. Patrimonio cultural de la obra pública. Acciones del pasado, propuestas del futuro. In Jornadas Patrimonio Industrial y Obra Pública; Biel, M.P., Ed.; Gobierno de Zaragoza: Zaragoza, Spain, 2007; pp. 206-212. Available online: http://www. patrimonioculturaldearagon.es/documents/10157/675f026a-1329-4dff-9542-ab001c451bef (accessed on 20 January 2021).

9. García de Miguel, J.M. La conservación del patrimonio de la obra civil al inicio del siglo XXI y sus riesgos. Ing. Territ. 2010, 92, 4-11. Available online: http:/ / oa.upm.es/8721/2/INVE_MEM_2010_86045.pdf (accessed on 15 February 2021). 
10. Nárdiz, C. La estética de lo viejo, treinta años después. El reconocimiento progresivo y limitado del Patrimonio de las Obras Públicas. Rev. Obras Públicas 2012, 3, 19-34. Available online: http://ropdigital.ciccp.es/pdf/publico/2012/2012_\%20julioagosto_3534_\%2007.pdf (accessed on 20 May 2021).

11. Martínez Vázquez de Parga, R. Las obras públicas, un patrimonio poco valorado. Rev. Obras Públicas. Col. Ing. Caminos Canales Puertos 1997, 38, 86-89.

12. Bernabeu, J.; Berrocal, A.B.; Hernández, P.; López, A.; Hernández, V. La consideración patrimonial de las obras públicas. In Criterios de Intervención en el Patrimonio Arquitectónico del Siglo XX; Ministeros de Educación y Cultura: Madrid, Spain, 2011; pp. 231-240.

13. Ballester, J.M. Evolución del concepto de patrimonio cultural en Europa: La incorporación de las obras públicas. Rev. Obras Públicas 2014, 3599, 7-12. Available online: http:/ / ropdigital.ciccp.es / pdf/publico/2014/2014_noviembre_3559_02.pdf (accessed on 3 March 2021).

14. Addis, B.; Miller, J. Civil engineering heritage: Country profile-England. Eng. Hist. Herit. 2017, 170, 80-86. [CrossRef]

15. Cox, R.; Gould, M.H. Civil Engineering Heritage; Thomas Telford Ltd.: London, UK, 1998.

16. Isohata, H. Civil engineering heritage: Country profile-Japan. Eng. Hist. Herit. ICE 2016, 2, 95-100. [CrossRef]

17. ASCE-American Society of Civil Engineering. Historic Civil Engineering Landmark Program. Available online: https://www. asce.org/landmarks/ (accessed on 20 May 2021).

18. IEA-Institution Engineers Australia. Engineering Heritage Recognition Program. Available online: https://www.engineersaustralia. org.au/resource-centre/resource/australian-engineering-heritage-register (accessed on 20 May 2021).

19. Fernández-Ordoñez, J.A. Catálogo de Puentes Anteriores a 1936; Colegio de Ingenieros de Caminos, Canales y Puertos: Madrid, Spain, 1984.

20. Fernández-Ordóñez, J.A. Catálogo de Treinta Canales Españoles Anteriores a 1900; MOPU: Madrid, Spain, 1986.

21. Fernández-Ordoñez, J.A. Catálogo de Noventa Presas y Azudes Españoles Anteriores a 1936; Colegio de Ingenieros de Caminos, Canales y Puertos: Madrid, Spain, 1988.

22. Aguilar, I. Las Obras Públicas, 100 Elementos del Paisaje Valenciano; Conselleria d'Obres Públiques i Transports: Valencia, Spain, 2005.

23. Aguilar, I.; Aguiló, M. Guía de Puentes de la Comunitat Valenciana; Consejería de Infraestructura y Medio Ambiente, Generalitat Valenciana: Valencia, Spain, 2016.

24. De las Casas, A. Guía de Obras Públicas en Andalucía; Colegio de Ingenieros de Caminos, Canales y Puertos: Madrid, Spain, 2014.

25. Sánchez Beitia, S. Catálogo de Faros Con Valor Patrimonial en España; Instituto del Patrimonio Cultural de España: Madrid, Spain, 2017.

26. Romero, D. El patrimonio documental de las obras públicas y las exposiciones: Cómo se enseña y se difunde. Rev. Obras Públicas. Col. Ing. Caminos Canales Puertos 2014, 3559, 43-50.

27. Hernández-Lamas, P.; Ruiz-Bedia, M.L. Patrimonio y Paisaje de la Ingeniería Civil. In I Jornada de Trabajo; Universidad de Cantabria: Santander, Spain, 2014.

28. Ruiz-Bedia, M.L.; Hernández-Lamas, P.; Castro, O. Difusión del paisaje y patrimonio a través de las nuevas tecnologías. In Proceedings of the REHABEND, Congreso Latinoamericano Sobre Patología de la Construcción, Tecnología de la Rehabilitación y Gestión del Patrimonio, Santander, Spain, 1-4 April 2014; pp. 2215-2221.

29. Hernández-Lamas, P.; Cabau, B. Geography of Torroja's works: An app for the geolocation and dissemination of his works. In Proceedings International Conference on Construction Research, Eduardo Torroja AEC; Instituto de Ciencias de la Construcción y Fundación Eduardo Torroja: Madrid, Spain, 2018; pp. 383-390.

30. Hernández Lamas, P.; Ruiz Fernández, R. Proyecto piloto G•O•ING Grandes Obras de Ingeniería. Rev. Obras Públicas. Col. Ing. Caminos Canales Puertos 2019, 3613, 58-67. Available online: http://ropdigital.ciccp.es/pdf/publico/2019/2019_octubre_3613.pdf (accessed on 21 May 2021).

31. Hernández-Lamas, P. GEOPACK. App para Geolocalización del Patrimonio Construido. Cuad. Diseño Obra Pública 2013 , 5, 36.

32. Castro, O.; Sarabia, A. El sentido de catalogar: De los estudios históricos y los inventarios a las nuevas aplicaciones. Rev. Obras Públicas. Col. Ing. Caminos, Canales y Puertos 2014, 3559, 73-78.

33. Alvarenga, A.; Matos, F.; Godina, R.; Matias, J. Digital transformation and Knowledge Management in the Public Sector. Sustainability 2020, 12, 5824. [CrossRef]

34. Tabrizi, B.; Lam, E.; Girard, K.; Irvin, V. Digital Transformation is Not About Technology. Harv. Bus. Rev. 2019. Available online: https:/ / hbr.org/2019/03/digital-transformation-is-not-about-technology (accessed on 10 November 2021).

35. Marchegiani, L. Digital Transformation and Knowledge Management; Routledge-Giappichelli Studies in Business and Management; Routledge: London, UK, 2021.

36. Haydar, M.; Roussel, D.; Madjid Maïdi, S.O.; Mallem, M. Virtual and augmented reality for cultural computing and heritage: A case study of virtual exploration of underwater archaeological sites (preprint). Virtual Real. 2011, 15, 311-327. [CrossRef]

37. García-Gómez, I.; Fernández de Gorostiza, M.; Mesanza Moraza, A. Láser escáner y nubes de puntos. Un horizonte aplicado al análisis arqueológico de edificios. Arqueol. Arquit. 2011, 8, 25-44. Available online: https://arqarqt.revistas.csic.es/index.php/ arqarqt/article/view/126/122 (accessed on 10 November 2021).

38. Torres, J.C.; Cano, P.; Melero, J.; España, M.; Moreno, J. Aplicaciones de la digitalización 3D del patrimonio. Virtual Archaeol. Rev. 2010, 1, 51-54. [CrossRef]

39. Ministerio de Transporte, Movilidad y Agenda Urbana. ¿Qué es BIM? Available online: https://www.esbim.es (accessed on 16 January 2021). 
40. Pauwels, P.; Verstraeten, R.; De Meyer, R.; Van Campenhout, J. Architectural Information Modelling for virtual heritage application. In Proceedings of the 14th International Conference on Virtual Systems and Multimedia, Digital Heritage, Limassol, Cyprus, 20-25 October 2008; pp. 18-23. Available online: https:/ / biblio.ugent.be/publication/434809/file/481646.pdf (accessed on 21 November 2021).

41. Murphy, M.; McGovern, E.; Pavia, S. Historic building information modelling (HBIM). Struct. Surv. 2009, 27, 311-327. [CrossRef]

42. Nieto Julián, J.E.; Moyano, J.; Rico Delgado, F.; Antón, D. La necesidad de un modelo de información aplicada al patrimonio arquitectónico. In Proceedings of the 1er Congreso Nacional BIM-EUBIM, Valencia, Spain, 24-25 May 2013; Volume 1, pp. 1-13.

43. González Pérez, C. Information Modelling for Archaeology and Amthropology: Software Engineering Principles for Cultural Heritage; Springer International Publishing AG: Cham, Switzerland, 2018.

44. Korro Bañuelos, J.; Rodríguez Miranda, Á.; Valle Melón, J.M.; Zornoza Indart, A.; Castellano Román, M.; Angulo Fornos, R.; Pinto-Puerto, F.; Acosta Ibáñez, P.; Ferreira-Lopes, P. The Role of Information Management for the Sustainable Conservation of Cultural Heritage. Sustainability 2021, 13, 4325. [CrossRef]

45. Barazzetti, L.; Banfi, F.; Brumana, R.; Previtali, M.; Roncoroni, F. Bim From Laser Scans ... Not Just for Buildings: Nurbs-Based Parametric Modeling of a Medieval Bridge. ISPRS Ann. Photogramm. Remote Sens. Spat. Inf. Sci. 2016, III-5, 51-56. [CrossRef]

46. Pinto Puerto, F.; Guerrero Vega, J.M. Imagen y modelo en la investigación del patrimonio arquitectónico. Virtual Archaeol. Rev. 2013, 4, 135-139. [CrossRef]

47. Angulo Fornos, R. Digital models applied to the analysis, intervention and management of architectural heritage. WIT Trans. Built Environ. 2015, 149, 407-418.

48. Stone, R.; Ojika, T. Virtual heritage: What next? IEEE Multimed. 2000, 7, 73-74. [CrossRef]

49. Guarnieri, A.; Pirotti, F.; Vettore, A. Cultural Heritage interactive 3D models on the web: An approach using open source and free software. J. Cult. Herit. 2010, 11, 350-353. [CrossRef]

50. Mañana-Borrazás, P. Utilidades del pdf3D. Digital CSIC. 1 December 2012. Available online: http://digital.csic.es/handle/10261/ 63515 (accessed on 21 September 2021).

51. Champion, E.; Rahaman, H. 3D Digital Heritage Models as Sustainable Scholary Resources. Sustainability 2019, 11, 2425. [CrossRef]

52. Potenziani, M.; Callieri, M.; Dellepiane, M.; Corsini, M.; Ponchio, F.; Scopigno, R. 3DHOP: 3D Heritage Online Presenter. Comput. Graph. 2015, 52, 129-141. [CrossRef]

53. Martí Testón, A. Hacia Una Museografía 4.0. Diseño de Experiencias Inmersivas Con Dispositivos de Realidad Aumentada; Universidad Politécnica de Valencia: Valencia, Spain, 2018.

54. Wu, H.-K.; We-Yu Lee, S.; Chang, H.-Y.; Liang, J.-C. Current status, opportunities and challenges of augmented reality in education. Comput. Educ. 2013, 62, 41-49. [CrossRef]

55. De la Torre-Cantero, J.; Saorín, J.L.; Meier, C.; Melián-Díaz, D.; Díaz Alemán, M. Creación de réplicas de patrimonio escultórico mediante reconstrucción 3D e impresoras 3D de bajo coste para uso en entornos educativos. Arte Individuo Soc. 2015, 27, 429-446. Available online: http:/ / www.redalyc.org/articulo.oa?id=513551298005 (accessed on 21 July 2021).

56. Tejado Sebastián, J.M. Escaneado en 3D y prototipado de piezas arqueológicas: Las nuevas tecnologías en el registro, conservación, y difusión del patrimonio arqueológico. Iber. Rev. Antigüedad 2005, 8, 135-158. Available online: https: / / publicaciones.unirioja. es / ojs/index.php/iberia/article/view/303 (accessed on 15 July 2021).

57. Hernández-Muñoz, Ó.; Sánchez-Ortiz, A. Digitalización e impresión 3D para la reconstrucción de pérdidas volumétricas en un modelo anatómico de cera del siglo XVIII. Conserv. Património 2019, 30, 59-72. [CrossRef]

58. Cano, M.; Abellán, A.; Tomás, R.; Riquelme, A. Structure from Motion (SfM): Una técnica fotogramétrica de bajo coste para la caracterización y monitoreo de macizo rocosos. In Proceedings of the 10 Simposio Nacional sobre Ingeniería Geotécnica, A Coruña, Spain, 19-21 October 2016; Volume 1, pp. 209-215.

59. Gagliolo, S.; Ausonio, E.; Federici, B.; Ferrando, I.; Passoni, D.; Sguerso, D. 3D cultural heritage documentation: A comparision between different photogrammetric software and their products. In Proceedings of the ISPRS TC II Mid-term Symposium “Towards Photogrammetry 2020" Mid-Term, Riva del Garda, Italy, 4-7 June 2018; Volume XLII-2, pp. 4-7. Available online: https:/ / pdfs.semanticscholar.org/5b17/d45bd4583f1227caebd06109022c803cb3d5.pdf (accessed on 20 October 2021).

60. Rahaman, H.; Champion, E. To 3D or Not 3D: Choosing a Photogrammetry Workflow for Cultural Heritage Groups. Heritage 2019, 2, 1836-1851. [CrossRef]

61. Pereira-Uzal, J.M.; Robledano-Arillo, J. Uso de tecnologías 3D en la digitalización y difusión de documentos de alto valor patrimonial. El Profesional Información 2013, 22, 215-223. [CrossRef]

62. Cotec. Innovación en El Sector del Patrimonio Histórico; Fundación Cotec para la Innovación Tecnológica: Madrid, Spain, 2010. Available online: https://docs.google.com/viewerng/viewer?url=https://static.eoi.es/savia/documents/componente67126.pdf (accessed on 7 September 2021).

63. Patrimonio de las Universidades Andaluzas. Available online: http:/ / atalaya3d.ugr.es/index.php (accessed on 29 July 2021).

64. 3D-ICONS. 3D Digitalisation of Icons of European Architectural and Archaelogical Heritage. Available online: http://3diconsproject.eu (accessed on 29 July 2021).

65. Peinado Santana, S. La Documentación 3D del Patrimonio Inmueble: Gestión, Conservación y Difusión; Universidad Politécnica de Madrid: Madrid, Spain, 2019. 
66. Guidazzoli, A.; Liguori, M.C.; Chiavarini, B.; Verri, L.; Imboden, S.; De Luca, D. From 3D Web to VR historical scenarios: A cross-media digital heritage application for audience development. In Proceedings of the 23rd International Conference on Virtual System \& Multimedia (VSMM), Dublin, Ireland, 31 October-4 November 2017; IEEE: Dublin, Ireland, 2017 ; pp. 1-8.

67. Statham, N. Scientific rigour of online platform for 3D visualization of heritage. Virtual Archaeol. Rev. 2019, 10, 1-16. [CrossRef]

68. Svoboda, J.; Škereň, M.; Květoň, M.; Fiala, P. Holographic 3D imaging-Methods and applications. J. Phys. Conf. Ser. 2013, 415, 012051. [CrossRef]

69. Lipson, A.; Lipson, S.G.; Lipson, H. Optical Physics; Cambridege University Press: Cambridege, UK, 2010.

70. Ruiz Torres, D. Realidad aumentada, educación y museos. ICONO 14 Rev. Científica Comun. Tecnol. Emerg. 2011, 9, $212-226$. [CrossRef]

71. GitHub. Available online: https:/ / github.com/Ultimaker/Cura (accessed on 29 July 2021).

72. Slic3r. Open Source 3D Printing Toolbox. Version 1.3.0. Available online: https:/ / slic3r.org (accessed on 29 July 2021 ).

73. Repetier. Version 2.1.6, Windows. Available online: https:/ /www.repetier.com (accessed on 29 July 2021).

74. Aguiló, M. El Carácter de los Puentes Españoles; ACS: Madrid, Spain, 2007.

75. GOING. Grandes Obras de la Ingeniería. Available online: http://ingenieria-civil.org/GOING/buscador.php (accessed on 2 August 2021).

76. Chías Navarro, P.; Abad Balboa, T. Puentes de España; FCC: Madrid, Spain, 1994; pp. 154-155.

77. Hispania Nostra, Lista Roja del Patrimonio. Available online: https://listarojapatrimonio.org/ (accessed on 2 August 2021).

78. MeshLab. Version 2016. Available online: http://meshlab.net (accessed on 29 July 2021).

79. Comes, R.; Neamţu, C.; Zsolt, B.; Bidiu, I. Methodology to create 3D models for augmented reality applications using scanned point clouds. Mediterr. Archael. Archaeom. 2014, 14, 35-44.

80. Cignoni, P.; Callieri, M.; Corsini, M.; Dellepiane, M.; Ganovelli, F.; Ranzuglia, G. MeshLab: An open-source mesh processing tool. In Eurographics Italian Chapter Conference; Eurographics Digital Library: Pisa, Italy, 2008; pp. 129-136.

81. Interactive Geometry Lab. ETH Zurich, Department of Computer Sciences. Available online: https://igl.ethz.ch/projects/ instant-meshes / (accessed on 19 July 2021).

82. Blender. Available online: https:/ / www.blender.org/ (accessed on 21 July 2021).

83. Palacios Estremera, C. Pirámide holográfica rápida. Facultad de Ciencias. Universidad de Navarra: Departamento de Física y Matemática Aplicada. 2013, pp. 1-8. Available online: https://www.unav.edu/documents/29007/8773000/videc_f05.pdf (accessed on 12 September 2021).

84. OpenShot. Available online: https:/ / www.openshot.org/ (accessed on 25 October 2021).

85. Portalés, C.; Lerma, J.L.; Pérez, C. Photogrammetry and augmented reality for cultural heritage applications. Photogramm. Rec. 2009, 24, 316-331. [CrossRef]

86. Rahaman, H.; Champion, E.; Bekele, M. From photo to 3D to mixed reality: A complete workflow for cultural heritage visualisation and experience. Digit. Appl. Archaeol. Cult. Herit. 2019, 13, e00102. [CrossRef] 